\section{Using Nitrogen Balance to Calculate Fertilization in Strawberries}

\author{
N.F. Gariglio, ${ }^{1}$ R.A. Pilatti, ${ }^{1}$ \\ and B.L. Baldi²
}

ADDITIONAL INDEX WORDS. strawberry, nitrogen fertilization, nitrogen balance

Summary. In Santa Fe, Argentina, strawberries (Fragaria xananasa D uch.) are cultivated in the area of Coronda where $\mathbf{N}$ fertilization usually exceeds crop requirements. The objective of this work was to test four types of fertilization methodology to optimize fertilizer use efficiency. Experiments were carried out at the horticultural center of the Facultad de Agronomía y Veterinaria, in Esperanza, Santa $\mathrm{Fe}, 31.15^{\circ} \mathrm{S}$ latitude, on a typical argiudol soil. 'C handler' was planted $13 \mathrm{M}$ ar. 1996. N itrogen demand was related to the dry matter production with $\mathbf{N}$ content decreasing to increment of biomass (W), soil $N$ mineralization was estimated according to the program EDAFO version 3.

$U$ sing previous data, a monthly balance was calculated and four treatments were devised: control (T 0$)=$ without fertilization; treatment 1 (T 1$)=\mathbf{N}$ fertilization covering the accumulated monthly deficit, $53 \mathrm{~kg} \cdot \mathrm{ha}^{-1}$ (47 lb/ acre); treatment 2 (T 2) = N fertiliza tion covering the monthly deficit 66 kg'ha-1 (58 lb/ acre); treatment 3 (T3) $=\mathbf{N}$ fertilization covering the total crop demand $117 \mathrm{~kg} \cdot \mathrm{ha}^{-1}$ (104 lb/ acre). All $\mathbf{N}$ treatments significantly increased yields over the control. Yield increased to increasing $\mathbf{N}$ rates from $\mathbf{0}$ to 53 $\mathrm{kg} \cdot \mathrm{ha}^{-1}$. This response was due to an increase in fruit number but not in fruit weight. $\mathrm{H}$ igh $\mathrm{N}$ rates promoted

\footnotetext{
Facultad de Agronomía y Veterinaria de Esperanza. U niversidad $\mathrm{N}$ acional del Litoral, Kreder 2805, 3080Esperanza, Provincia de Santa Fe. Argentina.

This project was sponsored by CAI + D. Secretary of Science and Technology of the $U$ niversidad $\mathrm{N}$ acional del Litoral. The cost of publishing this paper was defrayed in part by the payment of page charges. U nder postal regulations, this paper therefore must be hereby marked adverti sement solely to indicate this fact.

1Professor of plant physiology; e-mail: ngarigli@unl.edu.ar.

${ }^{2}$ Auxiliary student ad-honorem.
}

runner growth without increasing fruit yield. The use $\mathbf{N}$ balance method for strawberry fertilization showed satisfactory results. Accumulated $\mathbf{N}$ balance (T1), required the least amount of $\mathbf{N}$ fertilizer while producing good yield, thus it should be the method adopted to reduce costs and environmental risks of $\mathbf{N}$ fertilization.

I

n Santa Fe, Argentina, 4000 ha (1000 acres) of strawberries arecultivated in thearea of Coronda, al ong the river of the same name. Fertigation is used to minimize percolation losses, optimize nutrient applications and to satisfy crop water demand.

Preplantfertilizersgenerallyexceed the $\mathrm{N}$ necessary, as reported in Spain (Guimera et al., 1995) and Florida (Albregts et al., 1991), where recommended rates were $>220 \mathrm{~kg} \cdot \mathrm{ha}^{-1}$ (196 $\mathrm{lb} /$ acre). I n recent works, ratesdecreased to 100 to $150 \mathrm{~kg} \cdot \mathrm{ha}^{-1}$ (89 to $134 \mathrm{lb} /$ acre) (Albregts et al., 1996; H ochmuth et al., 1996) due to split applications based on the requirements of the different phenological phases. Some experiments have demonstrated further reductions in N applications are possible. H uman and Kotze (1990) obtained maximum yields with fractionated, autumn and spring applications, of 70 $\mathrm{kg} \cdot \mathrm{ha}^{-1}$ (62 lb/ acre).

In Coronda, traditional base applicationsare made with 10 to $15 \mathrm{t}^{\mathrm{ha}} \mathrm{h}^{-1}$ (4 to 6 tons/ acre) of chicken manure followed by balanced chemical N-P-K fertilizers applied in spring (Scaglia et al., 1985). This convention probably exceedscrop demandsgreatly. The soils of this area show very high base levels of nutrients. In the case of phosphorus, it is common to find values ranging from 60 to $500 \mathrm{mg} \cdot \mathrm{L}^{-1}$ (ppm), while in uncultivated soils, the levels are around $8 \mathrm{mg} \cdot \mathrm{L}^{-1} \mathrm{~N}$, due to its mobility, doesn't remain in the soil but rather percolates toward the aquifers (Guimera et al., 1995). In some areas of I srael with a long agricultural history, it was found that the heavy use of $\mathrm{N}$ fertilizers caused an increase in the nitrates of aquifers, from 40 to 105 $\mathrm{mg} \cdot \mathrm{L}^{-1}$ in a 30 -year period ( $\mathrm{H}$ agin and Lowengart, 1996).

These considerations establish the necessity to modify the traditional fertilization based on requirements at the different phenological crop phases. The objective of thiswork isto test four types of $\mathrm{N}$ fertilization practices to optimize fertilizer use efficiency. 


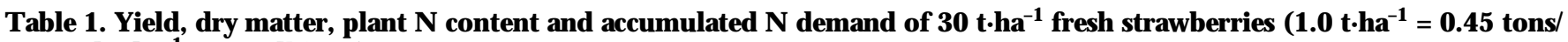
acre, $1 \mathrm{~kg} \cdot \mathrm{ha}^{-1}=0.89 \mathrm{lb} /$ acre).

\begin{tabular}{|c|c|c|c|c|c|c|c|c|c|}
\hline \multirow[b]{2}{*}{ Parameter } & \multicolumn{9}{|c|}{ Month } \\
\hline & March & April & May & J une & J uly & August & September & October & November \\
\hline Fruit/ ha $\left(\mathrm{t} \cdot h \mathrm{~h}^{-1}\right)$ & & & & & & 3.0 & 7.5 & 16.5 & 30.0 \\
\hline N (\%) & 4.2 & 4.2 & 4.2 & 4.2 & 4.2 & 3.7 & 2.3 & 1.7 & 1.7 \\
\hline $\mathrm{N}$ demanded $\left(\mathrm{kg} \cdot \mathrm{ha}^{-1}\right)$ & 0.8 & 4.2 & 8.4 & 16.8 & 33.6 & 44.6 & 56.9 & 80.1 & 116.6 \\
\hline
\end{tabular}

Table 2. Soil $\mathbf{N}$ mineralization, accumulated $\mathbf{N}$ demand by crops, monthly and accumulated $\mathbf{N}$ balance. $\mathbf{N}$ itrogen balance is the difference between $\mathrm{N}$ demand by crops and available soil $\mathrm{N}\left[{ }^{\circ} \mathrm{F}=1.8\left({ }^{\circ} \mathrm{C}\right)+32\right]$.

\begin{tabular}{|c|c|c|c|c|c|c|c|c|c|c|}
\hline \multirow[b]{2}{*}{ Parameter $^{2}$} & \multicolumn{9}{|c|}{ Month } & \multirow[b]{2}{*}{ T otal } \\
\hline & March & April & May & June & July & August & September & October & November & \\
\hline Soil temperature & & & & & & & & & & \\
\hline $\begin{array}{l}\text { Soil N mineralization } \\
\left(\mathrm{kg} \cdot \mathrm{ha}^{-1}\right)\end{array}$ & 8 & 7 & 6 & 6 & 6 & 6 & 7 & 8 & 10 & 64 \\
\hline $\begin{array}{l}\text { D emanded } \mathrm{N} \\
\left(\mathrm{kg} \cdot \mathrm{ha} \mathrm{C}^{-1}\right)\end{array}$ & 0.84 & 3 & 4 & 8 & 17 & 11 & 12 & 23 & 36 & 117 \\
\hline $\begin{array}{l}\text { M onthly N balance } \\
\left(\mathrm{kg} \cdot \mathrm{ha}^{-1}\right)\end{array}$ & 7 & 4 & 2 & -3 & -11 & -5 & -5 & -15 & -27 & -66 \\
\hline $\begin{array}{l}\text { Total N balance } \\
\left(\mathrm{kg} \cdot \mathrm{ha}^{-1}\right)\end{array}$ & 7 & 11 & 13 & 10 & -1 & -6 & -11 & -26 & -53 & -53 \\
\hline
\end{tabular}

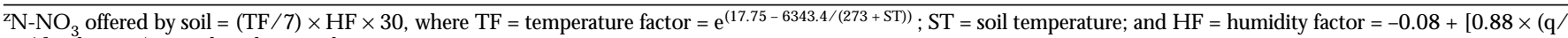
$\mathrm{qcc})$ ], where $\mathrm{q} / \mathrm{qcc}$ is the relative soil water content.

\section{Materials and methods}

The research was carried out at the horticultural experimental center of the Facultad deAgronomíay Veterinaria, in E speranza, (31.15 lat. S, 60 long.) on a typical argiudol soil with $0.128 \%$ total $\mathrm{N} ; 0.010 \%$ stabilized organic $\mathrm{N} ; 35$ $\mathrm{mg} \cdot \mathrm{L}^{-1}(\mathrm{ppm})$ soluble $\mathrm{P}$ and $1.1 \mathrm{meq} \%$ of interchangeable $K$.

The outplanting was done 13 M arch 1996 with cold stored plants of 'Chandler', a short day cultivar. Plants were established in the field on double rows $60 \mathrm{~cm}$ ( 24 inches) apart with a path of $40 \mathrm{~cm}$ (16 inches) within plant spacing was $25 \mathrm{~cm}$ (10 inches), with a density of 80,000 plants/ ha $(32,000$ plants/ acre). The rows were covered with black plastic mulch. D rip tapewith emitters every $20 \mathrm{~cm}$ (8 inches) positioned between rows was used. Watering was done when the tension of the soil reached $-30 \mathrm{kPa}$.

$M$ aturefruit wereharvested twicea week to touch total production and fruit weight average. Five plants were sampled monthly for weight of root, crown, leaves, inflorescence and runners as fresh and dry matter.

A randomized complete block design with four replications and four treatments was used; the experimental met was a double row $4.25 \mathrm{~m} \mathrm{(14ft)}$ long.

$\mathrm{N}$ demand for the crop was calculated from a fitted curve of dry matter increased over time (Gariglio et al., 1995), for a prospective production of $30 \mathrm{t} \cdot \mathrm{ha}^{-1}$ (12 tons/ acre) of fresh fruit (Table1). TheN content in thebiomass was estimated from $\mathrm{N}$ decline with increment of biomass (W). (G reenwood et al., 1990).

The $\mathrm{N}-\mathrm{NO}_{3}{ }^{-}$soil mineralization per month (Table 2) was calculated according to the program EDAFO version 3 (Pilatti and G renón, 1996) from total $\mathrm{N}$ content corrected by an $\mathrm{N}$ mineralization factor as a fraction of on soil temperature and humidity.

Treatments defined by $\mathrm{N}$ balance (difference between $\mathrm{N}$ demand and soil availability), were as follows:

Table 3. Strawberry yields components to different $\mathrm{N}-\mathrm{NO}_{3}$ fertilization rates (1 $\mathrm{kg} \cdot \mathrm{ha}^{-1}=0.89 \mathrm{lb} / \mathrm{acre}, 305 \mathrm{~g} \cdot \mathrm{m}^{-2}=1 \mathrm{oz} / \mathrm{ft}^{2}, 10.8 \mathrm{fruit} / \mathrm{m}^{2}=1 \mathrm{fruit} / \mathrm{ft}^{2}, 28.35 \mathrm{~g}=$ $1.0 \mathrm{oz})$.

\begin{tabular}{|c|c|c|c|c|}
\hline $\begin{array}{l}\mathrm{N}-\mathrm{NO}_{3} \\
\left(\mathrm{~kg}^{-1} \cdot \mathrm{ha}^{-1}\right) \\
\end{array}$ & $\begin{array}{c}\text { Yield } \\
\left(g \cdot m^{-2}\right)\end{array}$ & $\begin{array}{c}\text { Yield } \\
\left(\text { fruit } / \mathrm{m}^{2}\right)\end{array}$ & $\begin{array}{c}\text { Fruit wt } \\
\text { (g) }\end{array}$ & $\begin{array}{c}\text { Total biomass } \\
\left(\mathrm{g} \cdot \mathrm{m}^{-2} \text { dry matter }\right)\end{array}$ \\
\hline 0 & $286.4 a^{2}$ & $279 a$ & $10.26 \mathrm{a}$ & 693 a \\
\hline 53 & $305.5 \mathrm{~b}$ & $294 \mathrm{~b}$ & $10.40 \mathrm{a}$ & $737 \mathrm{~b}$ \\
\hline 66 & $312.5 \mathrm{~b}$ & $299 \mathrm{~b}$ & $10.45 \mathrm{a}$ & 792 b \\
\hline 117 & $318.4 \mathrm{~b}$ & $298 \mathrm{~b}$ & $10.68 \mathrm{a}$ & $1018 \mathrm{c}$ \\
\hline
\end{tabular}

${ }^{\mathrm{z} V}$ alues followed by the different letter, represent significant differences, according to Tukey test for $\alpha=0.05$. 


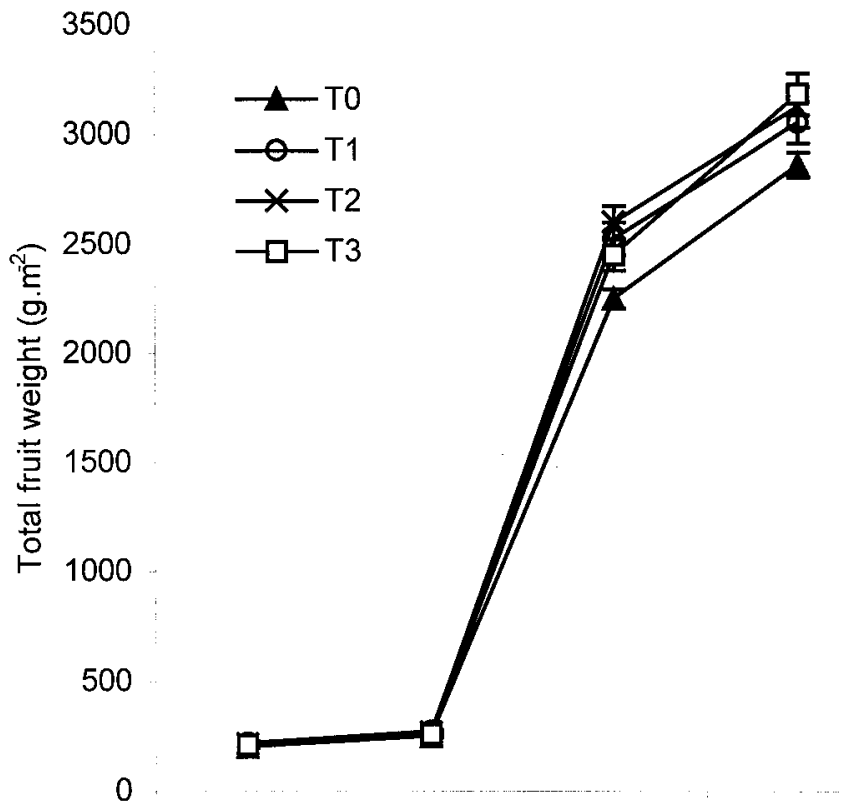

August September October November

Fig. 1. Effects of four different $\mathbf{N}$ treatments on accumulated strawberry production during the harvest period. $\mathrm{TO}=$ control, without $\mathrm{N}$ fertigation; $\mathrm{T} 1=\mathrm{N}$ fertigation covering the accumulated monthly deficit, $53 \mathrm{~kg}^{\prime} \mathrm{ha}^{-1}(47 \mathrm{lb} / \mathrm{acre}) ; \mathrm{T} 2$ = $\mathrm{N}$ fertigation covering the monthly deficit, $66 \mathrm{~kg}^{\prime} \mathrm{ha}^{-1}$ ( $\left.59 \mathrm{lb} / \mathrm{acre}\right) ; \mathrm{T} 3=\mathrm{N}$ fertigation covering the total crop demand, $117 \mathrm{~kg}^{\prime} \mathrm{ha}^{-1}$ (104 lb/acre).

\section{Results and discussion}

All $\mathrm{N}$ treatments significantly increased yields over the control (T able 3). Yield increased to increasing $\mathrm{N}$ rates from 0 to $53 \mathrm{~kg} \cdot \mathrm{ha}^{-1}(47 \mathrm{lb} /$ acre). This response was an increase in fruit number but not in fruit weight. This type of response was observed in previous research ( $\mathrm{H}$ ochmuth, et al., 1996), stronger in soillessmedia, where only $\mathrm{N}$ concentration in the nutrient solution was varied (Rindom and $H$ ansen, 1995).

E arly fruit yield did not respond to the treatments (Fig. 1), but increased greatly in $\mathrm{O}$ ctober and $\mathrm{N}$ ovember. D uring these months the great fruit and the total biomass was produced ( $T$ able 4) and the soil was deficient in N (T able 2). H ochmuth et al. (1996), found the best responses to $\mathrm{N}$ fertilization at peak fruit production.

The weight of the fruit is influenced by factors other than $\mathrm{N}$ fertilization. Aging of the plant and fruit position in the inflorescence ( $\mathrm{H}$ ortynski et al., 1991) reduces fruits size; a seconds fruit is $70 \%$ of a firsts fruit, thirds, and

Table 4. Accumulated total biomass (dry matter) $\left(1 \mathrm{~kg}^{\prime} \mathrm{ha}^{-1}=0.89 \mathrm{lb} / \mathrm{acre}\right)$ and partition of assimilates in strawberry.

\begin{tabular}{|c|c|c|c|c|c|c|c|c|}
\hline \multirow{2}{*}{$\begin{array}{l}\text { Nitrogen } \\
\left(\mathbf{k g}^{\prime} \mathbf{h a}^{-1}\right)\end{array}$} & \multirow{2}{*}{$\begin{array}{l}\text { D ry matter } \\
\left(\mathrm{kg}^{\left.-\mathrm{ha}^{-1}\right)}\right.\end{array}$} & \multicolumn{7}{|c|}{ Month } \\
\hline & & May & June & July & August & September & October & November \\
\hline \multirow[t]{6}{*}{0} & L eaves & 108 & 632 & 808 & 1340 & 1884 & 2536 & $2412 a$ \\
\hline & Root & 28 & 68 & 96 & 172 & 436 & 112 & $292 a$ \\
\hline & Crown & 20 & 80 & 124 & 324 & 548 & 348 & $616 a$ \\
\hline & Flowers & 40 & 8 & 0 & 0 & 0 & 1032 & $748 a$ \\
\hline & Fruit & 47 & 53 & 55 & 55 & 100 & 2234 & $2864 a$ \\
\hline & $\begin{array}{l}\text { Total } \\
H \text { arvest index }=41 \%\end{array}$ & 243 & 1001 & 1083 & 1891 & 2968 & 6262 & $6932 \mathrm{a}$ \\
\hline \multirow[t]{3}{*}{53} & Leaves & 100 & 892 & 1184 & 1576 & 1112 & 2172 & $2776 a b$ \\
\hline & Root & 12 & 64 & 72 & 268 & 284 & 104 & 132 a \\
\hline & Crown & 4 & 124 & 104 & 304 & 464 & 692 & 544 a \\
\hline \multirow[t]{3}{*}{53} & Flowers & 0 & 20 & 0 & 0 & 0 & 2360 & $864 \mathrm{a}$ \\
\hline & Fruit & 72 & 79 & 81 & 81 & 126 & 2478 & $3055 b$ \\
\hline & $\begin{array}{l}\text { Total } \\
\mathrm{H} \text { arvest index }=41 \%\end{array}$ & 208 & 1567 & 1441 & 2229 & 1986 & 7806 & $7371 b$ \\
\hline \multirow[t]{3}{*}{66} & L eaves & 108 & 580 & 972 & 872 & 1392 & 2008 & $2380 a$ \\
\hline & Root & 16 & 25.2 & 116 & 108 & 208 & 676 & $268 a$ \\
\hline & Crown & 16 & 80 & 92 & 160 & 356 & 504 & $512 a$ \\
\hline \multirow[t]{3}{*}{66} & Flowers & 32 & 8 & 0 & 0 & 0 & 1072 & $1636 \mathrm{~b}$ \\
\hline & Fruit & 51 & 56 & 56 & 56 & 113 & 2571 & $3125 b$ \\
\hline & $\begin{array}{l}\text { Total } \\
H \text { arvest index }=39 \%\end{array}$ & 223 & 1009 & 1236 & 1196 & 2069 & 6831 & 7921 b \\
\hline \multirow[t]{6}{*}{117} & Leaves & 108 & 816 & 1928 & 1560 & 1408 & 2756 & 3064 b \\
\hline & Root & 60 & 64 & 184 & 292 & 428 & 376 & $900 \mathrm{~b}$ \\
\hline & Crown & 40 & 100 & 244 & 344 & 388 & 500 & $828 b$ \\
\hline & Flowers & 40 & 8 & 0 & 0 & 0 & 976 & $2208 c$ \\
\hline & Fruit & 38 & 48 & 51 & 51 & 96 & 2411 & $3184 b$ \\
\hline & $\begin{array}{l}\text { Total } \\
\text { Harvest index }=31 \%\end{array}$ & 286 & 1744 & 2407 & 2247 & 2320 & 7019 & 10184 c \\
\hline
\end{tabular}




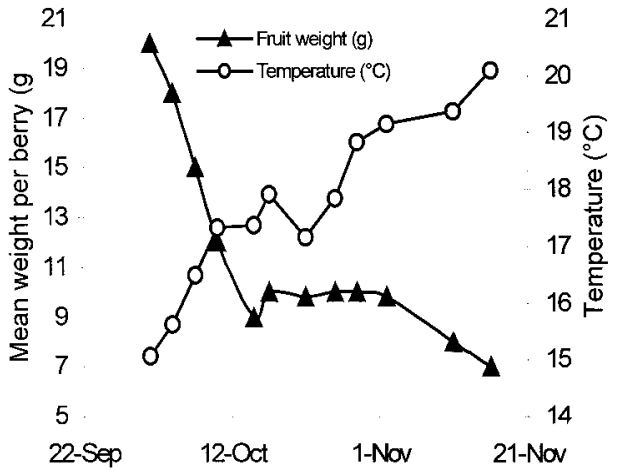

Fig. 2. E volution of average daily temperature and mean strawberry weight along harvest period in Santa Fe, Argentina, $31.15^{\circ} \mathrm{S}$ latitude.

fourths fruits $37 \%$ and $21 \%$ respectively (M iura et al., 1994).

Temperature is the main environmental factor that affects the fruit size, because warmth decreases the growth period and the daily growth rate (M iura et al., 1994). This could explain, the reduction of fruit sizeduring thegrowth season (Fig. 2) and the low fruit weight in the Coronda area, over the harvest period (Table 3 ).

Total biomass, showed significant differencesamong $\mathrm{N}$ treatments(Tables 3 and 4), but was not correlated with fruit production. N itrogen fertilization increased total biomass and decreased the harvest index (dry matter fruit/ dry matter total $\times 100$ ) due to a bigger partition toward leaves and runners (Table 4).

Strawberries have increased photosynthesis rates and dry matter is partitioned to leaves and runners when the environmental conditions are unfavorableto flowering, (Schaffer etal., 1986). $\mathrm{H}$ igh temperature affects flowering and favor runner development in strawberry (Durner et al., 1987), which is enhanced by $\mathrm{N}$ fertilization and long days (T afazoli and Shaybany, 1978).

In our climatic conditions $\geq 50 \%$ of the total biomass (Table 4) was produced in 2 months ( $\mathrm{O}$ ctober and $\mathrm{N}$ ovember) and optimal availability of nu- trient in the soil was necessary, but a supply of $\mathrm{N}$ that exceeds crop demand, in combination with temperature and photoperiod of those months, promotes runner production.

In conclusion, $\mathrm{N}$ fertilization in Santa Fe, Argentina, can improve fruit yield, but high $\mathrm{N}$ rates applied under long day and high temperature conditions, promotes runner growth without increasing fruit production. Theuseof theN balancemethod for strawberry fertilization showed satisfactory results. Accumulated $\mathrm{N}$ balance (T I), required the least amount of $\mathrm{N}$ fertilizer while producing good yield, thusit should bethemethod adopted to reduce costs and environmental risks of $\mathrm{N}$ fertilization.

\section{Literature cited}

Albregts, E.E., G.A. Clark, C.C. Stanley, F.S. Zazueta, and A.G. Smajstrla. Preplant fertilization of fruiting microirrigated strawberry. 1991. H ortScience 26(9):11761177.

Albregts, E.E., G. H ochmuth, C.K. Chandler, J. Cornell, and J. H arrison. 1996. Potassium fertigation requirements of drip I rrigated strawberry. J. Amer. Soc. Hort. Sci. 121(1):164-168.

Durner, E.F., E.B.Poling, and E.A. Albregts. 1987. E arly season yield responses of selected strawberry cultivars to photoperiod and chilling in a Florida winter production system. J. Amer. Soc. H ort. Sci. 112(1):5356.

Gariglio, N.F., R.A. Pilatti, R.P. M arano, J.L. Berra, and D. Piumatti. 1995. Fertilización nitrogenada del cultivo de frutilla. H ort. Arg. 14(37):1-8 Jul-D ic.

Guimera, J., O . M arfá, L. C andela, and L. Serrano. 1995. N itrate leaching and strawberry production under drip irrigation management. Agr. Ecosys. Environ. 56: 121135.

Greenwood, D .J, G. Lemaire, G. Gosse, P. Cruz, A. D raycott, and J.J. N eeteson. 1990. D ecline in percentage $\mathrm{N}$ of $\mathrm{C}_{3}$ and $\mathrm{C}_{4}$ crops with increasing plant mass. Ann. Bot. 66:425-436.
$\mathrm{H}$ agin, J and A. Lowengart. 1996. Fertigation for minimizing environmental pollution by fertilizers. Fert. Res. 43:5-7.

H ochmuth, G.J ., E.E. Albregts, C.C.C handler, J. Cornell, and J. H arrison. 1996. $\mathrm{N}$ itrogen fertigation requirements of dripirrigated strawberries. J. Amer. Soc. H ort. Sci. 121(4):660-665.

H ortynski, J.A., J.Zebrowska, J. Gawronski, and T. H ulewics. 1991. Factors influencing fruit size in the strawberry (Fragaria ananassa Duch.). Euphytica 56:67-74.

H uman, C. and W.A. Kotze. 1990. Effect of nitrogen and potassium fertilization on strawberries in an annual hill culture system: 1 . Yield and fruit size. Commun. Soil Sci. Plant. Anal. 21(9-10), 771-782.

M iura, H ., M. Yoshida, and A. Yamasaki. 1994. Effects of temperature on the size of strawberry fruit. J. Jpn. Soc. Hort. Sci. 62(4):769-774.

Pilatti, M.A. and D.A. Grenón. 1996. Programa EDAFO versión 3. Software de administración y prosesamiento de datos edáficos. Cátedras de Edafología y de Agromática FAVE (UNL).

Rindom, A. and P. $\mathrm{H}$ ansen. 1995. Effects of fruit numbersand plant statuson fruit sizein the strawberry. Acta Agr. Scand. Sect. B, Soil Plant Sci. 45:142-147.

Sarooshi, R.A. and G.C. Cresswell. 1994. Effects of hidroponic solution composition, electrical conductivity and plant spacing on yield and quality of strawberries. Austral. J. Expt. Agr. 34:529-535.

Scaglia, E., J. Cabral, L. H evia, R. Bisinella, and N. Bearzi. 1985. Cinturón hortícola de la ciudad de Santa Fe. Boletín H ortícola de la Asociación Argentina de $\mathrm{H}$ orticultura. Año 4.7:73-85. Ext. 37. Instituto $\mathrm{N}$ acional de Tecnología Agropecuaria, Estación Experimental Agropecuaria Rafaela.

Schaffer, B., J.A. Barde, and J.M . Williams. 1986. Whole plant photosynthesis and drymatter partitioning in fruiting and deblossomed day-neutral strawberry plants. J. Amer. Soc. H ort. Sci. (3):430-433.

Tafazoli, E. and B. Shaybany. 1978. Influenceof nitrogen, deblossoming, and growth regulator treatments on growth, flowering, and runner production of the ' $\mathrm{Gem}$ ' everbearing strawberry. 